\title{
Seamus Heaney and the Belfast Group: Revising on His Own
}

\author{
Ashby Bland Crowder \\ Professor Emeritus at Hendrix College, Arkansas, USA
}

Copyright (c) 2016 by Ashby Bland Crowder. This text may be archived and redistributed both in electronic form and in hard copy, provided that the author and journal are properly cited and no fee is charged for access.

\begin{abstract}
It was Seamus Heaney's practice to submit poems that were to appear in Death of a Naturalist to the Belfast Group. He did not, however, bring all of them for the weekly discussions and published some just as they had appeared in the journals they were first published in. He did some revising independent of the Group, and this essay argues that when Heaney revised on his own the principles of the Group influenced his practice: he was sometimes successful in those independent revisions, sometimes not. Two poems demonstrate his practice. His revisions of "The Barn" eliminated awkward repetition, achieved clarity, and enhanced the emotion of fear experienced by the boy character. The revisions he made on his own for "Ancestral Photograph", however, were not all successful; after the Group discussed the poem, Heaney made additional effective revisions, correcting all but one of the original missteps.
\end{abstract}

Key Words. Seamus Heaney, Manuscript Revision, Twentieth-century Irish Poetry, Belfast Group, "The Barn", "Ancestral Photograph".

Resumen. Seamus Heaney solía presentar los poemas que luego incluiría en Death of a Naturalist (Muerte de un naturalista) al 'Grupo de Belfast'. Aún así, no llevó todos los poemas de dicho volumen a las discusiones semanales del Grupo sino que utilizó versiones publicadas previamente en revistas. Este ensayo sostiene que incluso cuando Heaney hacía las revisiones por su cuenta estaba influido por los principios del Grupo y que las revisiones independientes no siempre eran exitosas. Aquí se analizan dos poemas, "The Barn" y "Ancestral Photograph". En el primer caso, las revisiones que Heaney llevó a cabo eliminaron una repetición torpe, lograron mayor claridad, y acentuaron la emoción de miedo experimentada por el muchacho protagonista. En cambio, las revisiones que el poeta realizó por su cuenta de "Ancestral Photograph" fueron menos logradas; después de que el Grupo examinara el poema, Heaney hizo oportunas revisiones adicionales, corrigiendo todos menos uno de los fallos originales.

Palabras clave. Seamus Heaney, revisión de manuscritos, poesía irlandesa del XX, Grupo de Belfast, "The Barn", "Ancestral Photograph".

In The Ulster Renaissance: Poetry in Belfast 19621972, Heather Clark argues for the importance of Philip Hobsbaum's writing workshop to those who participated in it. Clark concludes that this Belfast Group, as it was called, fostered a collaborative effort in the writing of poems and that this process led to - or at least contributed to - the flowering of the Northern Irish poets participating in it (2006: 1-2). In an earlier essay, I analyzed the revisions that Seamus Heaney made to the poems that he brought to the Belfast Group, where they were 
subjected to a strict going over by colleagues devoted to the principles of the New Criticism. That essay, "Seamus Heaney's Revisions for Death of a Naturalist" (2015), demonstrates that the Group had a real influence on Heaney's revisions of the poems he brought to the weekly meetings at Hobsbaum's flat. We are, of course, speaking of a time before Heaney became the confident, world famous poet. He was twenty-four years old in the spring of 1963 when Hobsbaum issued invitations for his workshop, and Heaney was "incredibly pleased to be noticed" (Parker 1993: 50). At the time, Heaney told Henri Cole, he "felt that I had some literary possibility, but I had no real confidence" (1997: 92).The poet had given an even stronger statement to Frank Kinahan - that he had in 1963 "absolutely no confidence as a writer" (1982: 407). ${ }^{1}$

Nonetheless, Heaney had mustered sufficient self-assurance to have published several poems before joining the Group, and he did not feel the need to bring all of his poems to the Group meetings. ${ }^{2}$ Some poems were published in Death of a Naturalist (1966) with little or no revision. "In Small Townlands" was published in three journals - Interest, March 1965: 48; The New Statesman, 16 April 1965: 611; and The Northern Review 1.2, 1965: 7) - "Poem" in The Northern Review 1.2 (1965: 8), and "Valediction" in Poetry Ireland (Spring 1965: 9), all just as they later appeared in Death of a Naturalist (1966). A couple of others, "Waterfall" and "Lovers on Aran", received only one or two minor punctuation alterations after their appearance together in Vogue (1 September 1965: 1356) and before they went straight on into the collection, bypassing the Group. ${ }^{3}$ What

1. Heaney was the victim of bullying by the more experienced poets in the Group (Crowder 2015: 95).

2. The most significant poems published before Heaney joined the Group were "Turkeys Observed" (Belfast Telegraph), though he revised this poem extensively before it went in Death of a Naturalist; "Mid-Term break" (Kilkenny Magazine); and "An Advancement of Learning" (Irish Times) (Parker 1993: 49).

3. Even some of the poems subjected to Group analysis left that experience unrevised and appeared subsequently in magazines and in the collection.$/$ we are mainly concerned with here is this question: How did Heaney revise when he was not responding to criticism from the Group?

There is one poem that Heaney revised extensively on his own - "The Barn" - and another, "Ancestral Photograph", that he revised on his own before bringing it to the Group and then again after the first revised version had been subjected to critical discussion at a Group meeting. Of course, reality was more complicated than the phrase "on his own" allows, because Heaney's natural habit was to show his poems to Marie, his wife, who was often critical; the couple would engage in a back-and-forth about various aspects of the poems - "The usual sea-saw", as Heaney put it. ${ }^{4}$

We know that Heaney had revised those poems subjected to the rigors of the Group in certain ways: he revised for clarity, for grammatical correctness, to avoid awkwardness, to produce a truer or livelier image, and to enhance psychological realism. We ask here - did he do the same when revising without the direct aid of the workshop? Did the critical influence of the Group extend to Heaney's revising practice when he revised on his own?

"The Barn" is one of a series of poems about a boy facing real-life struggles and fears that are large in imagination but perhaps not in fact. Immediately, we see Heaney revising to gain clarity and to produce a stronger emotion of

./. in their original state. These are "Churning Day" (Critical Quarterly Poetry Supplement 7, 1966: 89), "Scaffolding" and "Personal Helicon" (The New Statesman, 4 December 1964: 880 and 19 March 1965: 446, respectively). "Follower" was published in The New Statesman (3 December 1965: 888) with only the slightest alteration: "The sweating team turned round" instead of the original "around" (line 9). "Docker," under "Belfast Snapshots" (The Dublin Magazine, Spring 1965: 69), had only two hyphens eliminated. The title poem, "Death of a Naturalist", was so polished when Heaney brought it before the Group that no very significant changes were called for (see Crowder 2015:101-2, note 29).

4. Moreover, she was herself a member of the "exciting and controversial environment" of the writing workshop (Parker 1993: 51); at home, though, the atmosphere for criticism and revision must have been quieter and more relaxed (O’Driscoll 2008: 64). 
fear in his poem's boy character. He also makes changes in diction to avoid awkward repetition. "The Barn" was first published in the British version of Vogue magazine in September 1965, and the revisions we shall observe were carried out prior to the publication of the poem a year later in the collection Death of a Naturalist. ${ }^{5}$

Heaney struck the first word of the first line of "The Barn" for the sake of instant clarity. In Vogue the poem began, "Clean corn lay piled like grit of ivory." When the reader reaches the word "grit", he should know that the corn has been threshed, yet by beginning the line with "Threshed corn", as the revision has it, Heaney flashes the picture before the reader instantly. The elimination of "clean", which concept is fairly retained by the allusion to "ivory", makes way for the word to serve as a substitution for "bright" in line 10 as the adjective accompanying "spade". Thus Heaney reduced use of the word "bright" from three times to twice in the two stanzas, keeping it where it is most effective - to modify the fierce unblinking eyes that stare at the boy from the corners of the barn and to present realistically the boy's eyes' adjustment to reduced light after he enters the barn: "A scythe's edge, a clean spade, a pitch-fork's prongs: / Slowly bright objects formed when you went in" (Naturalist 1966: 17).

In the poem's final two stanzas, when the boy's daytime fears assume exaggerated proportions in his dreams, Heaney heightens the emotional tenor associated with the barn's darkness through adept revision. In the early version, he had written, "The dark yawned like a roof-space"; he altered the verb to "gulfed" (Naturalist 1966: 17). "Yawned" envisions the threat, but "gulfed' suggests that the boy feels swallowed up by it. ${ }^{6}$

"Ancestral Photograph," also based on Heaney's childhood memories, went through a more elaborate and uncertain process of revision, partly before it was brought to the group

\section{Hereafter cited thus: (Naturalist).}

6. As Heaney went from "yawned' to "gulfed", he might have been prompted by recollection of Robert Louis Stevenson's “yawning valley, gulfed in blackness" from Travels with a Donkey in the Cevennes (1910: 300). and partly afterwards, giving us an opportunity to see next to each other Heaney's solitary revision and that done with the help of his colleagues in the workshop. Like "The Barn," "Ancestral Photograph" was also published in Vogue, in September 1965; this is the version that Heaney revised before bringing the poem to the Group. Heaney on his own was not, in this case, so sure-footed as he was in revising "The Barn": his missteps involved both the description of the family photograph and the description of its absence. First, he introduced a pair of dashes that did not work grammatically. The Vogue (1965b: 135) version described the picture, in part, as follows:

A bowler suggests the stage Irishman Whose look has two parts scorn, two parts dead pan. His silver watch chain girds him like a hoop.

Revising for the Group sheet, which was passed out to all members of the workshop in advance, Heaney inserted dashes to create an interrupting clause, a move that turned the passage ungrammatical:

A bowler suggests the stage Irishman Whose look has two parts scorn, two parts dead pan His silver watch chain girds him like a hoop.

("Workshop") $)^{7}$

That these clauses do not fit nicely together is the sort of problem that one would expect to be pointed out during the Group discussion. Heaney might have repaired the problem by turning "girds" into a gerund, but he decided instead to forego the construction with dashes and return the passage to the form it had originally taken in Vogue magazine, putting a period after "pan" and making the middle line a simple adjective clause. Heaney must have, in the end, recognized, too, that "His silver watch chain girds him like a hoop" is a strong image and an effective conclusion to a stanza that pictures the photograph (Naturalist 1966: 26).

7. http:/www.beck.library.emory.edu/Belfast Group/ workshop.php; hereafter cited parenthetically thus: ("Workshop"). In addition to the Group sheets at Emory University's Beck Library, there is a set in the Irish Collection of Queen's University Library, Belfast. 
Heaney's second faulty revision was to the second stanza at the crucial point at which the poem describes the empty place on the wall where the ancestral photograph had once hung. In the poem's early version, "on the bedroom wall / There is a whitened patch where he has been" (Vogue 1965b: 135). Assuming that the bedroom wall was painted or papered white, the protected space where the photograph had hung would indeed be whiter than the rest of the wall, which, uncovered, would have faded over time. In revising for the Group sheet, however, Heaney misapplied his revising pen to strike "whitened" and then replaced it with "faded" ("Workshop"). ${ }^{8}$ Heaney's "faded" would properly describe the wall around the "patch" but certainly not the patch itself. Though the poem is devoted to memory - of the uncle fifty years ago and the speaker's own memory of twenty years ago - the taking down of the photograph whose "sepia tints" have begun "to fade" (Naturalist 1966: 26) takes place in the present speaking of the poem, and therefore there is no time for the patch to have become faded. Heaney surely had his reason for making the decision that he made, and we shall take it up presently.

Yet not all of the pre-Group revisions to the Vogue version of "Ancestral Photograph" were ineffective. Heaney enhanced the smooth flow of the third stanza, achieving at the same time changes in wording to reflect the real-life event remembered, and he rewrote the penultimate line to enhance clarity. He accomplished the first by resolving the two sentences of stanza three into one and altering the verbs in the stanza to portray more faithfully the actions of the cattlemen. In Vogue, the stanza had appeared as follows:

Twenty years ago I herded cattle

Into pens or held them against a wall

Until my father won at arguing

His own price on a crowd of cattlemen.

They handled teats, felt rumps, stood, paused and then

Bought a round of drinks to clinch the bargain.

(1965b: 135)

8. A passage in William Humphrey's The Ordways confirms the problem with Heaney's revision: when Tom Ordway observes "the wall above the mantle" where a photograph had once hung, he saw the "original, unfaded, pristine patterned wallpaper" (1964: 133).
In revising this passage before bringing the poem before the Group, Heaney eliminated the full stop after "cattlemen" and, in the next line, substituted "Who" for "They", thereby providing a seamless picture of the buying and selling of cattle. ${ }^{9}$ Then the cattlemen's examination of the cows was reformulated: now they "handled rumps, groped teats," this new order of the procedure reflecting how the actions would naturally be carried out; and "handled" seems more reflective than "felt" of the cattlemen's rough manner, as does "groped", which also portrays the uncertainty of the men as they reach for the teats. Perhaps, as well, there is something of the older meaning of the word "grope" - making an examination, probing $(O E D$, sense $4 \mathrm{c})$ intended.

The final revision carried out upon the Vogue version of the poem involved Heaney's rewriting the penultimate line to make it fitting and clear. As the speaker addresses his father, the poem had ended as follows: "A long chase ends here and I sense a kill / Taking your uncle's portrait to the attic" (1965b: 135). Why Heaney might initially have taken recourse to a generic British hunting metaphor ("thrill of the chase," "moving in for the kill") is unclear, but in revising he eliminated the cliché and remedied the uncertainty caused by that inappropriate metaphor. For the Group sheet, he changed the penultimate line to "Closing this chapter of our chronicle," ordinary language, to be sure, yet clear ("Workshop"). The head of the final line, "Taking" (in the Vogue version), seems to designate the speaker as taker, but for the Group sheet Heaney changed the word to "Take", which has the son inappropriately giving his father an order ("Workshop"). After the workshop discussion, Heaney gave the trip to the attic to the son ("I take"), and this is how the poem ends in Death of a Naturalist (1966: 26).

Apart from the addition of this first person pronoun, Heaney's revisions of the Group sheet sheet for "Ancestral Photograph" achieved

9. In the final stanza Heaney once again achieved a seamless flow by removing the halting commas in the following sentence: "the farmers shopped, like housewives, at an auction ring" ("Workshop"). 
clarity and correctness entirely by the manipulation of punctuation. In addition to removing those dashes in the first stanza, already remarked on, he added dashes in the second stanza, before and after a clause, to create an effective interruption, thereby clarifying a three-line sentence. In the version passed out to the Group, Heaney had written,

There is a faded patch where he has been

As if a bandage had been ripped from skin,

Empty plaque to a house's rise and fall.

("Workshop")

Before publication in Death of a Naturalist, Heaney placed a dash following "been" and "skin", removing the original comma after "skin". The setting off of the middle line as an interruption makes it clearer that the "faded patch" has become, for the speaker, an "Empty plaque to a house's rise and fall" (Naturalist 1966: 26). But why did Heaney retain the troubling term "faded" as modifier of the patch? Heaney must have made a conscious decision to sacrifice realism. There seems little doubt that Heaney wanted the plaque to be "faded" because it represents the family's fall from prominence in the farming community and the fading away of an aspect of Irish rural life that the speaker's father's uncle, the speaker's father, and the speaker himself had once participated in; to emphasize visually this fact was apparently more important to the poet than adhering to the logic that the patch would be the one spot that would not have faded. We are to understand that the speaker is not writing the poem, and we know that the speaker is staring at a white spot on the wall: it is the writer who overrules the experience of his character in making him see what is not actually present. I suppose readers might disagree about whether Heaney was justified in sacrificing reality to a thematic dimension. In a more perfect poem, realism and theme would be one.

At this early stage in his life as a poet, Heaney seems not always sure-footed in the revisions that he carried out. He was not incapable of revising effectively on his own, however, for his changes to "The Barn" prove that he made revisions, albeit minor ones, that did enhance his portrayal of the boy. Oddly, when Heaney initially revised "Ancestral Photograph" for the Group's critical eyes, he performed unevenly. Ultimately, the combination of his own ingenuity together with the good help of the Belfast Group led to his most successful revisions. It is not as though these revisions turned the poem from simmering to boiling: the changes were modest but not insignificant. Generally, he improved the clarity and correctness of his expression and, more importantly, provided livelier images and put right the psychological relationships of his characters. The only faulty revision that he retained for Death of a Naturalist was, we might say, like a photographic negative: had the image of the "Ancestral Photograph" been properly developed, that which is dark would have been white.

\section{Works Cited}

Clark, Heather. 2006. The Ulster Renaissance: Poetry in Belfast 1962-1972. Oxford: Oxford University Press.

Cole, Henri. 1997. "Seamus Heaney: The Art of Poetry LXXV," The Paris Review 144, Fall , 88-138.

Crowder, Ashby Bland. 2015. "Seamus Heaney's Revisions for Death of a Naturalist", New Hibernia Review 19.2, Summer, 94-112.

Heaney, Seamus. 1965a. "The Barn," Vogue, 1 September, 135.

1965b. “Ancestral Photograph,” Vogue, 1 September, 135.

1966. Death of a Naturalist. New York: Oxford University Press.

Humphrey, William. 1964. The Ordways. New York: Knopf.

Kinahan, Frank. 1982. “An Interview with Seamus Heaney,” conducted by Critical Inquiry 8.3, Spring, 407.

O’Driscoll, Dennis. 2008. Stepping Stones. New York: Farrar, Straus, and Giroux. 
Parker, Michael. 1993. Seamus Heaney, the Making of the Poet. Houndmills, Basingstoke: Macmillan.

Stevenson, Robert Louis. 1910 (1878). And Inland Voyage and Travels with a Donkey in the Cevennes. London New York: Charles E. Merrill Co.

Received 16 December 2015 Last version 11 January 2016

Ashby Bland Crowder is Peace Professor Emeritus of English, American Literature, and the Humanities at Hendrix College, Arkansas. He is the author of Wakeful Anguish, A Literary Biography of William Humphrey (Baton Rouge: Louisiana State University Press, 2004) and John Crowe Ransom: The Collected Poems (forthcoming from Louisiana State University Press) and editor of vols. 13, 17 of The Complete Works of Robert Browning (Athens, Ohio: Ohio University Press, 1995, 2012) and with Jason David Hall of Heaney: Poet, Critic, Translator (Houndmills, Basingstoke: Macmillan, 2007). 